\title{
SEXUAL DIMORPHISM IN RELATION TO MORPHOLOGICAL AND PHYSIOLOGICAL TRAITS IN JOJOBA, Simmondsia chinensis L. (Simmondsiaceae), A DIOECIOUS, XEROPHYTIC SHRUB.
}

(Received:9.11.2006)

\author{
By \\ M. M. Khattab, A.A.Hegazi, S. I. Laz* , and A. Z. Hassan* \\ Department of Pomology, Faculty of Agriculture, Cairo University. \\ *Department of Arid and Semi Arid Zone, Horticulture Research Institute, \\ Agricultural Research Center, Giza, Egypt.
}

\begin{abstract}
Morphological and physiological traits of male and female jojoba shrubs, a dioecious evergreen shrub of Sonora Desert were investigated. Morphological measurements included shoot length, and leaf length/width ratio.(L/W) Leaf nitrogen, carotene, and total phenol contents were also measured. The results indicated that males had a significant more shoot length, leaf L/W ratio, leaf nitrogen, and leaf carotene content than females, while females had a significant more leaf phenol content than males. Color reaction test in males was different than the color resulted from females. These results support the hypothesis stated that the high resource investment in fruit production by females reduces their growth and nitrogen content relative to males.
\end{abstract}

Key words: carotene, jojoba, leaf L/W ratio, nitrogen, phenols, Popov's test, sexual dimorphism, shoot length. Simmondsia chinensis .

\section{INTRODUCTION}

Dioecious plant species have been the subject of considerable research interest. Research has focused primarily on documenting differences between the sexual morphs in ecology, life history, and resource allocation. Many of dissimilarities between sexual morphs have been attributed to differences in reproductive biology that influence the relative allocation of resources to reproduction, growth, and maintenance (Lloyd and Web, 1977; Bierzychudek and Echart, 1988, cited in Cipollini and Whigham, 1994). Two allocation patterns or schedules have been suggested. First, fruit-producing plants may delay reproduction, thus channeling resources to growth and storage. Reproduction begins once a plant reaches a threshold of sufficient size and/or resource reserve. Second, because of fruit production, females allocate a greater portion of resources to reproduction than do males, and if resources are finite, then an increase in reproduction costs would result in a decrease in resources available to current growth as well as future growth and reproduction in terms of biomass, energy, and/or minerals. (Putwain and Harper, 1972; Lloyd, 1973; Lloyd and Web, 1977; Wallace and Rundel, 1979; Gross and Soule, 1981; Meagher and Antonovics, 1982;
Agren, 1988; Delph, 1990; Cipollini and Stiles, 1991; and Korpelainen, 1992).

Differential costs of reproduction may have other more subtle consequences for dioecious plants. According to the carbon/nutrient balance hypothesis (Coley et al., 1985) the assumption that females of dioecious plants bear greater reproduction costs in terms of nitrogen leads to the expectation of lower tissue nitrogen levels, and higher levels of C-based secondary compounds in females.( Elmqvist et al., 1988; and Jing and Coley, 1990).

Jojoba is one of the 5 most important xerophytic plants (Hinman, 1984), and it may be the first significant agricultured crop to supply many industries with raw material (Chen et al., 1985). The specific purposes of this study were to:

1. Find the morphological differences between mature males and females.

2. Physiological aspects to find the differences in nitrogen, carotene, and phenol contents between mature male and female.

\section{MATERIALS AND METHODS}

The present investigation was carried out on five year old jojoba shrubs (Simmondsia chinensis L.) grown at the experimental orchard of the Horticulture Research Institute in Giza Governorate, Egypt during 2003and 2004 
seasons.

This experiment was conducted to find out the morphological and physiological differences between the mature male and female jojoba shrubs. Ten seedy mature jojoba shrubs were selected, each sex was represented by five shrubs, each acts as a replicate. The shrubs were planted in loamy soil spaced at 3 by $3 \mathrm{~m}$ and received the same horticultural treatments. The experimental plants were similar in vigor, and free from any pathogens. On each shrub direction, twelve one year old shoots were selected per each replicate then tagged.

\subsection{Morphological characteristics}

The following morphological traits were measured at biweekly intervals from March $15^{\text {th }}$ in the first season and March $1^{\text {st }}$ in the second season to $1^{\text {st }}$ June in both seasons.

2.1.1 Average shoots length $(\mathrm{cm})$.

2.1.2 Leaf L/W ratio.

\subsection{Chemical and biochemical tests}

\subsubsection{Chemical tests}

\subsubsection{Nitrogen content}

Leaf samples were collected from the $3^{\text {rd }}$ to the $5^{\text {th }}$ node from the shoots tip of mature jojoba shrubs in July, cleaned, and dried at $70^{\circ} \mathrm{C}$ till constant weight then ground and used for determination of nitrogen content by the modified microKjeldahl method as described by Plummer (1971).

\subsubsection{Carotene content}

The quantitative analysis of carotene pigment (mg/g F.W.) was determined in samples of mature fresh leaves. The optimal densities were measured colorimetrically as adopted by Saric et al., (1976).

\subsubsection{Total phenols}

Mature leaf samples were collected from the $3^{\text {rd }}$ to the $6^{\text {th }}$ node from tips of jojoba shoots and used for the determination of total phenols by the method described by Daniel and George (1972).

\subsubsection{Biochemical test}

"Popov's test" was mentioned by Dzhaparidze (1967) and Chen et al., (1985) to differentiate between male and female throughout the resulted color from the reaction between the reagents and plant tissues.

\section{Popov's test}

Leaf samples of male and female mature jojoba plants were taken from the $3^{\text {rd }}$ to the $5^{\text {th }}$ nodes. The leaves were cleaned and cut into small pieces then ground in a mortar and pestle and extracted five times with $95 \%$ alcohol (5ml alcohol per 1 gram of tissue), then centrifuged at $10.000 \mathrm{rpm}$ for 10 minutes in a refrigerated centrifuge. Samples were run with $1 \mathrm{ml}$. of extracts of known sex jojoba plants. Colors were observed and recorded at various time intervals for 3 days.

\subsection{Statistical analysis}

The experimental materials (male and female) were arranged in randomized complete design. Each tree represented a replicate.

Data recorded in 2003 and 2004 seasons were subjected to analysis of variance according to Snedecor and Cochran (1980) and the means were differentiated using Duncan multiple tests at the $5 \%$ level of probability .

\subsection{Shoot length}

\section{RESULTS AND DISCUSSION}

Data shown in Table (1) represent the development of adult male and female jojoba shoot length from March $15^{\text {th }}$ to June $1^{\text {st }}$.This period involved vegetative growth and flowering in both sexes and harvesting time for females( in the first season.)

It is clear that the mean values of shoot length increased progressively irrespective of sex. The increase was gradual and insignificant in the period from March $15^{\text {th }}$ to May $15^{\text {th }}$, while it was notable when comparing with the corresponding values on March $15^{\text {th }}$ to May $15^{\text {th }}$. However, the increase was not prominent in the period from May $15^{\text {th }}$ to June $1^{\text {st }}$.

Concerning the relation between shoot length and sex, the mean value of shoot length proved to be significantly higher in males than females. Moreover, the percentage of increase in male shoot length from March $15^{\text {th }}$ to June $1^{\text {st }}$ was $17.1 \%$ although female percentage of increase was only $11.7 \%$.

The difference in shoot length rate between male and female in every date from March $15^{\text {th }}$ to June $1^{\text {st }}$ was insignificant, but in general, male shoots were longer than female ones.

Table (1): Mean shoot length of adult male and female jojoba shrubs in the first season (2003).

\begin{tabular}{|l|c|c|c|}
\hline Sampling dates & Male & Female & Mean \\
\hline $15 / 3$ & $28.70 \mathrm{ab}$ & $27.88 \mathrm{~b}$ & $28.29 \mathrm{~B}$ \\
\hline $1 / 4$ & $31.67 \mathrm{ab}$ & $28.91 \mathrm{ab}$ & $30.29 \mathrm{AB}$ \\
\hline $15 / 4$ & $32.59 \mathrm{ab}$ & $29.66 \mathrm{ab}$ & $31.13 \mathrm{AB}$ \\
\hline $1 / 5$ & $33.01 \mathrm{ab}$ & $29.97 \mathrm{ab}$ & $31.49 \mathrm{AB}$ \\
\hline $15 / 5$ & $33.53 \mathrm{a}$ & $30.89 \mathrm{ab}$ & $32.21 \mathrm{~A}$ \\
\hline $1 / 6$ & $33.61 \mathrm{a}$ & $31.16 \mathrm{ab}$ & $32.38 \mathrm{~A}$ \\
\hline Mean & $32.19 \mathrm{~A}$ & $29.74 \mathrm{~B}$ & \\
\hline
\end{tabular}

Means separation within column, line, or interaction each alone according to LSD 5\%.

Data of the second season as shown in Table (2) indicate that the mean values of shoot length increased progressively irrespective of sex. The increase was gradual and insignificant in the period from March $1^{\text {st }}$ to March15 $5^{\text {th }}$ and from March $15^{\text {th }}$ to April $1^{\text {st }}$, while it was notable and 
significant compared with the corresponding values on March $1^{\text {st }}$. Concerning the relation between shoot length and sex, mean value of shoot length proved to be significantly higher in males than females.

A gradual increase in shoot length was noticed in both sexes during the period of study but it was significant only in two dates $1 / 3$ and $15 / 4$.

The percentage of increase in male shoot from March $1^{\text {st }}$ to June $1^{\text {st }}$ was $20.3 \%$ although female percentage of increase was only $15.4 \%$ during the same period. Moreover, the difference in shoot length between male and female in every date from March $1^{\text {st }}$ to June $1^{\text {st }}$ was significant, and in general male shoots were longer than female ones.

A similar result was obtained by Lloyd and Webb (1977) who reported that in perennial, long-lived species, there are a onsiderable number of reports stating that male exceeded female in vigor, growth rates, total size or vegetative reproduction. Also, Cipollini and Whigham (1994) found that shoot length was slightly higher for males than females of Lindera benzion.

Table (2): Mean shoot length of adult male and female jojoba shrubs in the second season (2004).

\begin{tabular}{|l|c|c|c|}
\hline $\begin{array}{c}\text { Sampling } \\
\text { dates }\end{array}$ & Male & Female & Mean \\
\hline $1 / 3$ & $36.30 \mathrm{~cd}$ & $29.00 \mathrm{f}$ & $32.65 \mathrm{C}$ \\
\hline $15 / 3$ & $37.94 \mathrm{bc}$ & $30.95 \mathrm{ef}$ & $34.45 \mathrm{BC}$ \\
\hline $1 / 4$ & $41.65 \mathrm{ab}$ & $32.84 \mathrm{def}$ & $37.25 \mathrm{AB}$ \\
\hline $15 / 4$ & $42.60 \mathrm{a}$ & $33.26 \mathrm{de}$ & $37.93 \mathrm{~A}$ \\
\hline $1 / 5$ & $43.10 \mathrm{a}$ & $33.40 \mathrm{de}$ & $38.25 \mathrm{~A}$ \\
\hline $15 / 5$ & $43.39 \mathrm{a}$ & $33.46 \mathrm{de}$ & $38.42 \mathrm{~A}$ \\
\hline $1 / 6$ & $43.68 \mathrm{a}$ & $33.49 \mathrm{de}$ & $38.58 \mathrm{~A}$ \\
\hline mean & $41.24 \mathrm{~A}$ & $32.34 \mathrm{~B}$ & \\
\hline
\end{tabular}

Means separation within column, line, or interaction each

Contrarily, the obtained result did not agree with Lloyd and Webb (1977) who found that Mercurialis perennis L. females have taller stems (annual shoots arising from a perennial rhizome) than males, also Aggren (1988) reported that female shoots of Rubus chamaemorus were larger than male ones. Lynos et al., (1994) found that females have longer branches than males in Silene latifolia.

\subsection{Leaf $\mathrm{L} / \mathrm{W}$ ratio}

The results in Tables (3) and (4) represent the development of adult male and female jojoba leaf length/width ratio at the beginning of fruit lowering, set, and at fruit harvest in the two seasons of study, respectively.

The data of the first season reveal that mean values show an insignificant and gradual decrease in leaf $\mathrm{L} / \mathrm{W}$ ratio irrespective of sex.
Concerning leaf $\mathrm{L} / \mathrm{W}$ ratio and sex, the mean value proved to be significantly higher in males than in females.

The percentage of decrease in males L/W ratio during the season was $-2.47 \%$ while the percentage of decrease was $-2.43 \%$ in female ones.

The difference in leaf $\mathrm{L} / \mathrm{W}$ ratio between male and female on March $15^{\text {th }}$ and April $15^{\text {th }}$ was significant but it was insignificant on June $1^{\text {st }}$. In general leaf $\mathrm{L} / \mathrm{W}$ ratio was higher in males. The data of the second season in Table (4) prove the same trend of the first one.

It is clear that mean values show a decrease in leaf L/W ratio irrespective of sex. The decrease was gradual and insignificant.

Concerning leaf L/W ratio and sex, mean value proved to be significantly higher in males.

Also it was noticed that male and female leaf L/W ratio decreased progressively and insignificantly.

The difference in leaf $\mathrm{L} / \mathrm{W}$ ratio between male and female was significant and in general leaf $\mathrm{L} / \mathrm{W}$ ratio was higher in males. However the obtained result did not agree with Nigtevecht (1966, cited by Lloyd and Webb, 1977) who found that the leaves of female Silene alba were larger and had higher L/W ratio than those of male plants. Also Chen et al., (1985) reported that $\mathrm{L} / \mathrm{W}$ ratio of female jojoba leaves was higher than male ones.

Table (3): Mean leaf length/width ratio of adult male and female jojoba shrubs in the first season (2003).

\begin{tabular}{|l|c|c|c|}
\hline \multicolumn{1}{|c|}{ Sampling dates } & Male & Female & Mean \\
\hline $\begin{array}{l}\text { 15/3 beginning of } \\
\text { flowering }\end{array}$ & $3.116 \mathrm{a}$ & $2.632 \mathrm{bc}$ & $2.874 \mathrm{~A}$ \\
\hline $15 / 4$ Fruit set & $3.072 \mathrm{ab}$ & $2.589 \mathrm{c}$ & $2.830 \mathrm{~A}$ \\
\hline $\begin{array}{l}1 / 6 \text { harvest time for } \\
\text { female }\end{array}$ & $3.039 \mathrm{abc}$ & $2.568 \mathrm{c}$ & $2.803 \mathrm{~A}$ \\
\hline mean & $3.075 \mathrm{~A}$ & $2.596 \mathrm{~B}$ & \\
\hline
\end{tabular}

Means separation within column, line, or interaction each alone according to LSD $5 \%$.

Table (4): Mean leaf length/width ratio of adult male and female jojoba shrubs in the second season 2004

\begin{tabular}{|l|c|c|c|}
\hline \multicolumn{1}{|c|}{ Sampling dates } & Male & Female & Mean \\
\hline 1/3 beginning of flowering & $3.205 \mathrm{a}$ & $2.675 \mathrm{~b}$ & $2.940 \mathrm{~A}$ \\
\hline 15/4 Fruit set & $3.198 \mathrm{a}$ & $2.627 \mathrm{~b}$ & $2.913 \mathrm{~A}$ \\
\hline 1/6 harvest time for female & $3.196 \mathrm{a}$ & $2.605 \mathrm{~b}$ & $2.901 \mathrm{~A}$ \\
\hline mean & $3.193 \mathrm{~A}$ & $2.636 \mathrm{~B}$ & \\
\hline
\end{tabular}

Means separation within column, line, or interaction each alone according to LSD 5\%.

\subsection{Chemical tests}

The data in Table (5) represent jojoba adult male and female leaf carotene content, total phenols content, and nitrogen percentage content. Mean values of leaf carotene content proved to be 
significantly higher in males than in females. Conversely Dzhaparidze (1967) stated that the difference in carotene content is apparent: it is higher by almost $66 \%$ in female plants.

Table (5): Mean leaf total phenols content, carotene content, and nitrogen percentage content of adult male and female jojoba shrubs

\begin{tabular}{|l|c|c|c|}
\hline Sex & $\begin{array}{c}\text { Carotene } \\
\text { content } \\
(\mathbf{m g} / \mathbf{g} \text { F.W. })\end{array}$ & $\begin{array}{c}\text { Total phenols } \\
\text { content } \\
(\mathbf{g} / \mathbf{1 0 0 g})\end{array}$ & $\begin{array}{c}\text { Nitrogen } \\
\text { content } \\
\mathbf{\%}\end{array}$ \\
\hline Male & $0.4040 \mathrm{a}$ & $0.02875 \mathrm{~b}$ & $11.86 \mathrm{a}$ \\
\hline Female & $0.2236 \mathrm{~b}$ & $0.06018 \mathrm{a}$ & $8.58 \mathrm{~b}$ \\
\hline
\end{tabular}

Means separation within each column according to LSD 5\%.

Concerning the total phenol contents it is clear that the mean value of leaf total phenols content in females proved to be significantly higher than males. This result was also found by Cipollini and Whigham (1994).

Mean value of leaf nitrogen percentage proved to be significantly higher in males. Several previous studies of dioecious species have demonstrated comparatively higher male leaf nitrogen content (Wallace and Rundel, 1979; Tiedemann, et al., 1987; Allen and Antos, 1988; Jing and Coley, 1990; Cipollini and Stiles, 1991; and Nicotra et al., 2003).

\subsection{Biochemical test (Popov's test)}

The color resulted from female jojoba leaves was purple while the colors resulted from male jojoba leaves were dark purple and yellow. $80 \%$ of the tested samples of the male leaves resulted in a dark purple color but only $20 \%$ gave a yellow color. Concerning the female, it gave a purple color in $100 \%$ of the tested samples.

The same result was also found by Chen et al., (1985), as they mentioned that the color resulted from female jojoba shrubs was purple while the color resulted from male jojoba shrubs was dark purple. Dzhaparidze (1967), however, declared that the stain in popov's test was colorized in females but it was decolorized in males.

\section{REFERENCES}

Agren J. (1988). Sexual differences in biomass and nutrient allocation in the dioecious Rubus chamaemorus. Ecology 69: 962-973.

Allen G. A., and Antos J. A. (1988). Relative reproductive effort in males and females of the dioecious shrub Oemleria cerasiformis. Oecologia 76: 111-118.

Chen P. K., Fan C. J., O'Brien W., and Venketeswaran S. (1985). Preflowering sex determination: An aid to jojoba propagation. Proc. $6^{\text {th }}$ Intl. Conf. Jojoba and its uses, Ben Gurion Univ. of the Negev, Beer-Sheva, Israel.
Cipollini M. L., and Stiles E. W. (1991). Costs of reproduction in Nyssa sylvatica: Sexual dimorphism in reproductive frequency and nutrient flux. Oecologia 86: 585-593.

Cipollini M. L., and Whigham D. F. (1994). Sexual dimorphism and cost of reproduction in the dioecious shrub Lindera benzoin (Lauraceae). Amer. J. Bot. 81(1): 65-75.

Coley P. D., Bryant J. P., and Chapin F. S. (1985). Resource availability and plant antiherbivore defense. Science 230: 895-899.

Daniel H. O., and George C. M. (1972). Peach seed dormancy in relation to endogenous inhibitor and applied growth substance. J. Amer. Soc. Hort. 97:651-654.

Delf L. F. (1990). Sex- differential resource allocation patterns in the subdioecious shrub Hebe subalpina. Ecology 71: 1342-1351.

Dzhaparidze L. I. (1967). Sex in Plants part 2. Biochemical and Physiological Sex Differences in Dioecious Plants and Problems of Influencing Sex Formation. Clearinghouse for Federal Scientific and Technical Information. Springfield, Va.

Elmqvist T. L., Ericson K. D., and Salmonson A. (1988). Latitudinal sex ratio variation in willows, Salix spp., and gradients in vole herbivory. Oikos 51:259-266.

Gross K. L., and Soule J. D. (1981). Differences in biomass allocation to reproductive and vegetative structures of male and female plants of the dioecious, perennial herb, Silene alba (Miller) Krause. Amer. J. Bot. 68: 801807.

Hinman C. W. (1984). New crops for arid lands. Science 225:1445-1448.

Jing S. W., and Coley P. D. (1990). Dioecy and herbivory: The effect of growth rate on plant defense in Acer negundo. Oikos 58: 369-377.

Korpelainen H. (1992). Patterns of resource allocation in male and female plants of Rumex acetosa and Rumex acetosella. Oecologia 89: 133-139.

Lloyd D. G. (1973). Sex ratios in sexually dimorphic Umbellifera. Heredity 31: 239249.

Lloyd D. G., and Webb C. J. (1977). Secondary sex characters in plants. Bot. Rev. 43: 177216.

Lynos E. E., Miller D., Meagher T. R. (1994). Evolutionary dynamics of sex ratio and gender dimorphism in Silene latifolia: 1. Environmental effects. J. Hered. 85:196-203.

Meagher T. R., and Antonovics J. (1982). The population biology of Chamaelirium luteum, a dioecious member of the lily family: Life history studies. Ecology 63:1690-1700. 
Nicotra B. A., Chazdon R. L., and Montgomery R. A. (2003). Sexes show contrasting patterns of leaf and crown carbon gain in a dioecious rainforest shrub. Amer. J. Bot. 90(3): 347355.

Plummer D. B T. (1971). An Introduction to Practical Biochemistry. Mc Graw Hill Book Company. U. K. Limited.

Putwain P. D., and Harper J. L. (1972). Studies in the dynamics of plant population $\mathrm{v}$. mechanism governing sex ratio in Rumex acetosa and Rumex acetosella. J. Ecol. 60:113-129.

Saric M., Kastrori R., Curie R., Cupina T., and Gerie I. (1976). Chlorophyll Determination.
Univ. Unoven Sadu Parktikum Is Fiziologize Bibjoke, Beagard, Hauncna, Anjiga, pp.215.

Snedecor G. W., and Cochran W. G. (1980). Statistical Methods. $6^{\text {th }}$ edition. Iowa State Univ. Press, Ames, U.S.A..507 p.

Tiedemann A. R., McArther E. D., and Freeman D. C. (1987). Variations in physiological metabolites and chlorophyll in sexual phenotypes of 'Rincon' fourwing saltbush. J. Ran. Manag. 40(2): 151-155.

Wallace C. S., and Rundel P. W. (1979). Sexual dimorphism and resource allocation in male and female shrubs of Simmondsia chinensis. Oecologia 44: 34-39.

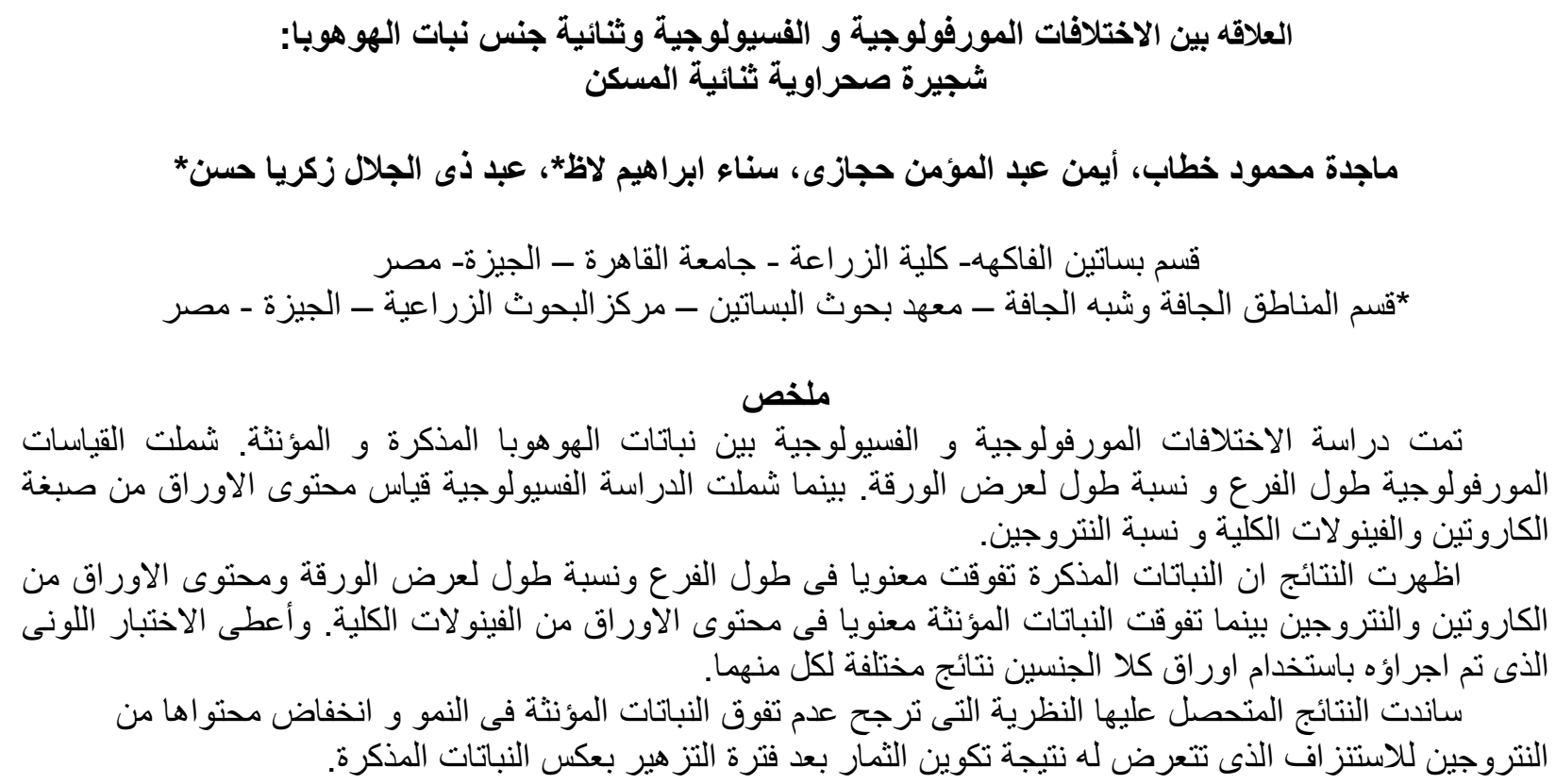

المجلة العلمية لكلية الزر اعة ـ جامعة القاهرة ـ المجلد (58) العددالثالث (يوليو 2007):207-.211 